American Journal of Agricultural and Biological Sciences 4 (4): 266-277, 2009

ISSN 1557-4989

(C) 2009 Science Publications

\title{
Response of Root Properties to Tripartite Symbiosis between Lucerne (Medicago sativa L.), Rhizobia and Mycorrhiza Under Dry Organic Farming Conditions
}

\author{
${ }^{1}$ M.R. Ardakani, ${ }^{2}$ G. Pietsch, ${ }^{2}$ A. Moghaddam, ${ }^{2}$ A. Raza and ${ }^{2}$ J.K. Friedel \\ ${ }^{1}$ Division of Sustainable Agriculture, Agriculture Research Center, \\ Islamic Azad University, Karaj Branch, Iran \\ ${ }^{2}$ Division of Organic Farming, Department of Sustainable Agricultural Systems, \\ University of Natural Resources and Applied Life Sciences, Vienna, Austria
}

\begin{abstract}
Problem statement: It is generally considered that root turnover is a major contributor to organic matter and mineral nutrient cycles in organic managed agroecosystems. Approach: This study designed to investigate whether microbial activity could affect on root properties of Lucerne in an organically managed field under dry weather conditions. The trial was laid out as a factorial experiment in the fields of the University of Natural Resources and Applied Life Sciences, ViennaAustria at Raasdorf in 2007. The experimental factors of Rhizobium (Sinorhizobium meliloti) and Arbuscular Mycorrhiza (AM) including Glomus etunicatum, G. intraradices and G. claroideum and irrigation levels were tested. Results: Results showed that increasing water deficit affected root dry weigh, specific root mass and root length significantly at $1 \%$ level and co-inoculation of rhizobium and mycorrhiza with irrigation increased all root parameters. Data's of variance analysis for mycorrhizal colonization showed that main effect of using mycorrhiza had significant effects on root parameters at 5 and $1 \%$ probability level at first and second harvest, respectively. Results of mean comparisons by Duncan's Multiple Range Test showed that mycorrhizal colonization was higher in the inoculated treatments by rhizobium, mycorrhiza and irrigated plots in both harvests. Double interaction of mycorrhiza and irrigation was higher in both harvests (37.05 and 65.73\%, respectively). Conclusion: It can be suggested that the tripartite symbiosis of Rhizobium, AM and Lucerne can improve the performance of Lucerne in organic farming and under dry conditions. Such traits could be incorporated into breeding programs to improve drought tolerance especially in organic fields.
\end{abstract}

Key words: Lucerne, root properties, mycorrhizal symbiosis, rhizobium, organic farming

\section{INTRODUCTION}

Most researches have focused on aboveground traits, relatively little attention has been paid to belowground processes such as root dynamics. Root production and mortality appear to occur simultaneously during the year and the stocks of live and dead roots reflect only the end products of these products. In other words, root accumulation in agroecosystems is ultimately controlled by the magnitude of root growth and turnover rates in the system ${ }^{[24,48]}$.

In recent years, agriculture has entered a period of major change. With increasing interest in sustaining economically viable crop production with minimal environmental impacts, farming without synthetic fertilizers and pesticides (organic farming) has been widely adopted as an alternative agricultural practice $^{[34,46]}$. Organic farming has to be self-sufficient in nutrients because the uses of chemical fertilizers are excluded. The cornerstone for soil fertility in organic farming is the use of those plants such legumes that are able to fix atmospheric $\mathrm{N}_{2}$ and also remain residue in the soil. Lucerne (Medicago sativa L.) is an important fodder legume in organic farming systems, mainly under dry site conditions. This plant improves the yield and quality of following crops by fixing nitrogen from the air ${ }^{[14,42]}$, reduces diseases and weeds, increase soil organic matter contents and improves water infiltration ${ }^{[16,38,44]}$. Also it has been well demonstrated that root production in such a plant like Lucerne found to be equivalent to, or greater than above-ground biomass ${ }^{[15,20,33]}$.

The amount of plant residues in the field has an important role to increase organic matter that improves soil fertility, microbial activity and water holding

Corresponding Author: Mohammad Reza Ardakani, Division of Sustainable Agriculture, Agriculture Research Center, 
capacity and other benefits that is very useful especially in the organically managed fields. Root growth and distribution could affect both plant growth especially in the extreme conditions and also increasing soil organic matter after harvesting the plants. In addition to Carbon (C), roots residues contain amount of plant-available Nitrogen $(\mathrm{N})$ and Phosphorus $(\mathrm{P})$, which can be recycled in field application, naturally. It is hence of great interest to develop methods allowing a good knowledge of plant root spatial distribution to explore the best rooting configuration to optimize the competition for water and nutrients ${ }^{[29]}$. Since, Water uptake depends on root size (length or mass), activity and spatial distribution, most existing research on roots has focused on morphology and growth. Mechanisms relating root distributions to their function can be determined by quantifying root length, diameter and associated surface area. This important information improves our understanding of root dynamics and associated functions in agroecological production systems.

Roots can respond to both internal ${ }^{[32]}$ and external controls (e.g., temperature, soil resources and water availability $\left.{ }^{[17]}\right)$. Understanding the mechanisms of root tolerance to drought conditions may further our understanding of root morphological traits associated with drought tolerance. On the other hand, studies of root systems growing in the field have to include the possibility that symbiotic associations (mycorrhiza and rhizobia) can significantly modify the hydraulic behavior of roots, with respect to that described under laboratory conditions. Soil microbial activity is considered a main parameter in ecosystem functioning. Arbuscular Mycorrhizal Fungi (AMF) is a mutualistic microsymbionts of about $90 \%$ of higher plants. Their well documented effect is the improvement of plantwater relations and increase water absorption ${ }^{[10,23]}$ and the enhancement of the uptake of phosphorus, as well as of other macro and micro elements, in sub-optimal situations ${ }^{[7,47]}$. It was also well documented that AMF colonization and AM fungal activity is enhanced by rhizobium, resulting in better plant performance ${ }^{[7,8,22,51]}$. AM fungi and Rhizobium spp. form an intimate association with leguminous plants, which is often termed the "tripartite symbiosis". Plants benefit from this association in many ways including enhanced plant growth, yield and nutrient content especially $\mathrm{N}$ and $\mathrm{P}^{[5,6]}$. In addition, research reports suggest that plant benefits derived from the tripartite symbiosis are superior to that of uninoculated control plants or that of plants inoculated with either AMF or rhizobium alone. Furthermore some reports suggest that differences between co-inoculations results are mediated by specific inter-endophyte interactions between rhizobium strains and the different AMF species, which became evident under $\mathrm{N}$-deficient conditions ${ }^{[9,30]}$.

The climate of eastern Austria is stamped by dry summers. The resulting low water supply can considerably impair the BNF rate of legumes, mycorrhizal activity and their constructive effect on soil fertility. In a preceding study ${ }^{[43]}$, Lucerne proved to be the most efficient legume under this dry condition.

In the context of water availability, the influence of irrigation as a factor affecting root survival was considered in this research. This study hypothesized that root biomass and other roots traits are varied in the presence of microbial symbiosis and may these microbial activities could improve root traits under dry organic farming conditions.

\section{MATERIALS AND METHODS}

Site description and weather conditions: The trial was located on the organically managed fields of the research station of the University of Natural Resources and Applied Life Sciences, Vienna, in Raasdorf (Length: $16^{\circ} 35^{\prime} 32^{\prime} \mathrm{E}>$ width: $48^{\circ} 13^{\prime} 53^{\prime} \mathrm{N}>$ height: 151 $\mathrm{m})$ in April 2007. Climate of this area is characterized by hot, dry summers with little dew and cold winters with little snow. The mean annual temperature is $9.8^{\circ} \mathrm{C}$, the average precipitation $554 \mathrm{~mm}$. Soil was Calcaric Phaeozems ${ }^{[58]}$ from Loess with a silty loam texture, organic carbon contents of $2.2 \%$ in the A horizon and a $\mathrm{pH}_{\mathrm{CaCl} 2}$ value of 7.6 in the topsoil. The soils are described in detail in Freyer et al. ${ }^{[21]}$.

Treatment variants differ with respect to the inoculation and irrigation of Lucerne (Table 1). The seeding density was $25 \mathrm{~kg} \mathrm{ha}^{-1}$ in all cases, Lucerne cultivar was Sitel (Origin and maintainer: Netherlands/Barenburg Holland BV, Atationsstraat 40, 6678 AC, Oosterhout; thousand seed weight: $2.3 \mathrm{~g}$ ).

The mean temperature in April 2007 (sowing trial) was $12.28^{\circ} \mathrm{C}$, which was more than monthly average $\left(9.7^{\circ} \mathrm{C}\right)$ and mean precipitation at this time was $0.80 \mathrm{~mm}$ which was very small amount precipitation in compare with monthly average $(38.8 \mathrm{~mm})$. Because of this dry condition and very low precipitation in mentioned time, sprinkler irrigation has been used for all treatments immediately after sowing.

Table 1: Treatment characters

\begin{tabular}{llll}
\hline Treatments & Rhizobia & Mycorrhiza & Irrigation \\
\hline $\mathrm{R}_{1} \mathrm{M}_{0} \mathrm{I}_{0}$ & + & - & - \\
$\mathrm{R}_{0} \mathrm{M}_{1} \mathrm{I}_{0}$ & - & + & - \\
$\mathrm{R}_{1} \mathrm{M}_{1} \mathrm{I}_{0}$ & + & + & - \\
$\mathrm{R}_{0} \mathrm{M}_{0} \mathrm{I}_{0}$ & - & - & - \\
$\mathrm{R}_{1} \mathrm{M}_{0} \mathrm{I}_{1}$ & + & - & + \\
$\mathrm{R}_{0} \mathrm{M}_{1} \mathrm{I}_{1}$ & - & + & + \\
$\mathrm{R}_{1} \mathrm{M}_{1} \mathrm{I}_{1}$ & + & + & + \\
$\mathrm{R}_{0} \mathrm{M}_{0} \mathrm{I}_{1}$ & - & - & + \\
\hline
\end{tabular}

-: Without application +: With application 
In the other months, May-September 2007 the temperature and precipitation were more or less same to the long term monthly average. Specially the precipitation most of the times was more than long term monthly average. The amount of precipitation from beginning of experiment until first harvest (12 April until 9 July) was $150.8 \mathrm{~mm}$ and from first harvest until second harvest (9 July-20 September) was $331 \mathrm{~mm}$. It shows that we had a large amount of precipitation (481.8 $\mathrm{mm})$ during the experiment.

Inoculation with Rhizobia and Mycorrhiza: The rhizobia used originated from the commercial inoculum collection of Becker Underwood Company with the trade name of Histick. The carrier material of inoculum's was sterilized peat based and contained minimum $2 \times 10^{9}$ viable cells of selected Sinorhizobium meliloti $\mathrm{g}^{-1}$. Lucerne seeds of each plot (30.56 $\mathrm{g} \mathrm{plot}^{-1}$ ) were inoculated with $6.5 \mathrm{~g}$ of rhizobium inoculum. Multispecific cultures of the AM species included Glomus etunicatum, G. intraradices and G. claroideum were produced by INOQ Agri company. The other characteristics of the inoculums are as follows: Carrier material, Vermiculite; Grain size: 1-2 mm; Specific weight: 570-610 g L L $\mathrm{gH}^{-1}$ : 5.7; Most Probable Number of propagules (MPN): $150 \pm 9$. The inoculums were previously weighted for each mycorrhizal plot $\left(850 \mathrm{~g} \mathrm{~m}^{-2}\right)$, spread congenial at the soil surface of each plot, then mixed with soil to $5 \mathrm{~cm}$ depth before sowing. After spreading and mixing mycorrhiza inoculum in the soil, Lucerne seeds sowed in the plots.

Irrigation: First irrigation has been done on 12 April 2007 for all the plots by sprinkler. After 7 weeks, irrigation for treatment was started. Five irrigations during the experiment and in each irrigation $12 \mathrm{~mm}$ plot $^{-1}$ were used for irrigated plots.

Experimental design and statistical methods: The research was laid out by factorial experiment in the form of Complete Randomized Block Design (CRBD) with 4 replicates; also mean comparisons for all parameters have been done by Duncan's Multiple Range Test (DMRT). All variants were presented in each replicate $(8 \times 4=32$ plots $)$. The area of each plot was $3 \times 3 \mathrm{~m}\left(9 \mathrm{~m}^{2}\right)$. Within each Lucerne plot, part of the area was designed for yield measurements without any destruction till end of the project (Harvest 1 and 2). Following a 4-way ANOVA ${ }^{[51]}$ with the factors "AM inoculation", "S. meliloti inoculation", "irrigation" and "block", means of the interaction combinations were compared by DMRT.
Root sampling and root parameters: Roots of different treatments of Lucerne to investigate root parameters were taken at first and second harvest $(\mathrm{H} 1$ : 09.07.2007 and H2: 20.09.2007), according to the development stage of the Lucerne crop at beginning of flowering. Using soil core method ${ }^{[12,36]}$ by an auger (10 $\mathrm{cm}$ diameter, $30 \mathrm{~cm}$ deep with 2 replicates per plot-one in row and one between rows).

The roots subsequently separated from soil by a hydro pneumatic elutriation system (Gillison's Variety Fabrication Inc., USA) through a sieve with a mesh of $760 \mu \mathrm{m}$, both large and fine terminal roots collected carefully. The procedure was conducted cautiously to prevent supplementary root damage and losses. After cleaning the roots, roots were stored in the bottles with full of water in the refrigerator at $4^{\circ} \mathrm{C}$ for later analysis. The commercial software package WinRHIZO 4.1 (Regent Instruments Inc., Quebec, Canada, 2000) which works under windows software program and uses a skeletonization method for measuring the root parameters, has been used for determination of root parameters. WinRHIZO uses a non statistical method for measuring root morphology. This method first presented at the American Society of Horticultural Science meeting held in Montreal (Qc. Canada) in $1995^{[3]}$. Optical scanners and digital cameras produce image files that are known as raster image. These images are made of an array of square pixels, a pixel (Picture Element) being the smallest element of an image. When an image is scanned at 600 dots per inch (dpi), every pixel is $1 / 600$ of an inch (or $0.042 \mathrm{~m}$ ) in size. WinRHIZO uses the information contained in the image files to compute morphological measurements. The roots then spread out over a transparent, water filled tray ( $8 \mathrm{~mm}$ water depth). The try is then placed on the scanner bed and the roots are scanned. Large roots cut into small segments, this procedure decreases the number of root overlaps, which are considered to be the major error source in root length estimation ${ }^{[13,28,45]}$.

After measuring root length by WinRHIZO, specific root length (root length density- $\mathrm{cm} \mathrm{cm}^{-3}$ ) is calculated as length of root per unit volume of soil. Specific root length is preferred over specific root mass, because the formation of mycorrhiza is not directly related to weight of roots. Also, specific root mass (root mass density $\mathrm{g} \mathrm{cm}^{-3}$ ) is calculated as weight of root per unit volume of soil. Root surface area calculated from the measured diameter with simple trigonometric formula. Root Area Index (RAI) is calculated with the following formula at second harvest: RAI = Root surface area/soil surface area.

Mycorrhizal colonization (\%) of roots is observed in the upper $0-30 \mathrm{~cm}$ of the soil profile. So, special care 
is required in collecting smaller roots because they easily break away from the main roots. In order to evaluation mycorrhizal colonization in Lucerne roots, after separating lateral roots, Ink-vinegar method for staining of mycorrhizal roots has been used that already described by Vierheilig et al. ${ }^{[54]}$. For quantification of colonized roots by AM fungi gridline intersection method has been used ${ }^{[56]}$. After washing the roots and its studies, roots of each treatment dried at $70^{\circ} \mathrm{C}$ for $72 \mathrm{~h}$ in the oven and root dry weight $\left(\mathrm{g} \mathrm{m}^{-2}\right)$ for each treatment is calculated. Dry weight of mycorrhizal roots $\left(\mathrm{g} \mathrm{m}^{-2}\right)$, calculated by multiplying the estimated percentage of root colonization by the dry weight of roots.

\section{RESULTS AND DISCUSSION}

Efficient water uptake is an important determinant of drought resistance and generally water uptake depends on root size (length or mass), root activity and spatial distribution. Extensive deep rooting often has been emphasized in relation to drought resistance ${ }^{[37,52]}$.

The tripartite association is relatively less well understood with respect to the factors that regulate it, compared to the rhizobium-legume symbiosis ${ }^{[56]}$. A worldwide database of measurements of root profiles showed that the average root mass ranged from about $200 \mathrm{~g} \mathrm{~m}^{-2}$ for croplands to about $5000 \mathrm{~g} \mathrm{~m}^{-2}$ for forests and sclerophyllous shrubs and trees ${ }^{[31]}$. In this research, root dry weight was on average $400 \mathrm{~g} \mathrm{~m}^{-2}$ at harvest 1 and $450 \mathrm{~g} \mathrm{~m}^{-2}$ at harvest 2 . It increased from harvest 1 to harvest 2 because of root growth (Fig. 1a-c). AM inoculation and irrigation significantly increased root dry weight at both harvests (Table 2). Al-Karaki and Al-Raddad ${ }^{[2]}$ reported root dry weight and total root length of wheat genotypes were reduced by drought stress but plant inoculated with $G$. mosseae had higher root dry weight than non-mycorrhizal plants. Inoculation with rhizobium slightly increased root dry weight at the first and second harvest (Fig. 1a), but not significantly (Table 2). Root development and distribution in soils are important for root-water and nutrient uptake studies in soil plant systems. In this way, AM inoculation may alleviate drought stress by enhancing water and nutrient uptake similar to the alleviating effects of AM on plant growth under extreme conditions ${ }^{[18,40,41]}$. AM inoculation did not affect Lucerne root growth upon rhizobium inoculation significantly (Table 2). Still, root dry weight was higher in the rhizobium and AM treatment, relative to the control treatment at harvest 1 (Fig. 1a and b), indicating a slight positive interaction. Neither rhizobium inoculation nor rhizobium $\mathrm{x}$ irrigation interaction affected root weight significantly (Table 2). But increased root weight in rhizobium treated plots versus control plots on the non-irrigated plots at second harvest (Fig. 1c) showed a positive rhizobium inoculation effect only under non-irrigated conditions. In annual crops, flowering (anthesis) appears to be a particularly important developmental stage after which assimilates are required to fill the growing grain leaving little for roots. In this case, most legumes are much less determinate than cereals, with flowering and grain filling occurring over a more prolonged period so that the demand for assimilates by the grain increases gradually. In consequence the root mass of many legumes continues to increase during flowering and early grain filling.

It has been suggested that mycorrhiza are relatively more important to plant growth under dry conditions than when soil moisture is plentiful ${ }^{[39]}$. Plant infected by arbuscular mycorrhizal fungi can tolerate and recover more rapidly from soil water deficit than uninfected plants ${ }^{[1,11,25,27]}$. Root hairs are very efficient in increasing the root surface area, although their effect on uptake may not be proportional because of competition among them. Plants and fungi have developed symbiotic associations. They act, at least partly, in a similar way but are more efficient than root hairs and provide for transport from the soil to the root over much larger distances than allowed by diffusion.

Table 2: Analysis of variance for measured traits

\begin{tabular}{|c|c|c|c|c|c|c|c|c|c|c|c|c|c|c|}
\hline \multicolumn{15}{|c|}{ Mean Square (MS) } \\
\hline SOV & $\mathrm{df}$ & RDW 1 & RDW 2 & MC 1 & MC2 & DWMR 1 & DWMR 2 & RL 1 & RL 2 & SRL 1 & SRL 2 & RLC1 & RLC 2 & RAI2 \\
\hline Replication & 3 & 337.27 & 594.92 & 11.765 & 9.623 & 174.92 & 631.28 & 2075.97 & 381.15 & 0.0000 & 0.0000 & 580.77 & 228.58 & 3.55 \\
\hline Rhizobium & 1 & $994.58 \mathrm{~ns}$ & $4974.28 \mathrm{~ns}$ & $21.61 \mathrm{~ns}$ & $58.40 \mathrm{~ns}$ & $901.29 *$ & $4699.59 \mathrm{~ns}$ & $11202.42 * *$ & $24926.42 * *$ & $0.0001 * *$ & $0.002 * *$ & $3218.17 * *$ & $15604.66 * *$ & $11.36 \mathrm{~ns}$ \\
\hline Mycorrhiza & 1 & $4645.99 *$ & $7510.17^{*}$ & $64.64 *$ & $934.30^{* *}$ & $3189.52 * *$ & $35912.83 * *$ & $71.67 \mathrm{~ns}$ & $22818.35^{* *}$ & $0.000 \mathrm{~ns}$ & $0.002 * *$ & $1284.36^{*}$ & $48700.66^{* *}$ & $1.03 \mathrm{~ns}$ \\
\hline Irrigation & 1 & $6683.41^{* *}$ & $36904.33^{* *}$ & $0.47 \mathrm{~ns}$ & $108.89 \mathrm{~ns}$ & $662.57^{*}$ & $25371.16^{* *}$ & $18488.20 * *$ & $35003.27 * *$ & $0.001^{* *}$ & $0.002^{* *}$ & $2036.25 * *$ & $24624.76^{* *}$ & $41.46^{*}$ \\
\hline $\mathrm{R} * \mathrm{M}$ & 1 & $1507.28 \mathrm{~ns}$ & $130.85 \mathrm{~ns}$ & $0.11 \mathrm{~ns}$ & $46.34 \mathrm{~ns}$ & $115.24 \mathrm{~ns}$ & $93.905 \mathrm{~ns}$ & $330.05 \mathrm{~ns}$ & $2045.60 \mathrm{~ns}$ & $0.000 \mathrm{~ns}$ & $0.000 \mathrm{~ns}$ & $62.96 \mathrm{~ns}$ & $321.46 \mathrm{~ns}$ & $0.48 \mathrm{~ns}$ \\
\hline $\mathrm{R} * \mathrm{I}$ & 1 & $658.66 \mathrm{~ns}$ & $3575.41 \mathrm{~ns}$ & $3.03 \mathrm{~ns}$ & $535.22 * *$ & $1.17 \mathrm{~ns}$ & $19637.90 * *$ & $7643.12^{* *}$ & $439.63 \mathrm{~ns}$ & $0.001 * *$ & $0.000 \mathrm{~ns}$ & $496.07 \mathrm{~ns}$ & $5913.01^{*}$ & $33.58^{*}$ \\
\hline $\mathrm{M}^{*} \mathrm{I}$ & 1 & $116.28 \mathrm{~ns}$ & $1867.67 \mathrm{~ns}$ & $21.42 \mathrm{~ns}$ & 76.97ns & $546.48 \mathrm{~ns}$ & $2685.45 \mathrm{~ns}$ & $70.42 \mathrm{~ns}$ & $416.81 \mathrm{~ns}$ & $0.000 \mathrm{~ns}$ & $0.000 \mathrm{~ns}$ & $333.81 \mathrm{~ns}$ & $31.08 \mathrm{~ns}$ & $5.25 \mathrm{~ns}$ \\
\hline $\mathrm{R}^{*} \mathrm{M} * \mathrm{I}$ & 1 & $829.87 \mathrm{~ns}$ & $95.32 \mathrm{~ns}$ & $0.70 \mathrm{~ns}$ & $598.84^{*}$ & $192.93 \mathrm{~ns}$ & $10031.83^{*}$ & $366.86 \mathrm{~ns}$ & $28984.49 * *$ & $0.000 \mathrm{~ns}$ & $0.002^{* *}$ & $17.02 \mathrm{~ns}$ & $40295.59^{* *}$ & $35.24 *$ \\
\hline Error & 21 & 455.42 & 1335.49 & 8.98 & 58.65 & 151.82 & 1858.97 & 658.48 & 1998.60 & 0 & 0 & 257.60 & 1348.99 & 7.61 \\
\hline c.v. & - & 5.24 & 7.67 & 8.58 & 12.75 & 8.66 & 14.95 & 6.44 & 9.63 & 6.44 & 9.63 & 11.53 & 13.06 & 19.99 \\
\hline
\end{tabular}

* and **: Significant at 5 and 1\% probability level, respectively, ns: Non-significant; RDW: Root Dry Weight, MC: Mycorrhizal Colonization, DWMR: Dry Weight of Mycorrhizal Roots, RL: Root Length, SRL: Specific Root Length, RLC: Root Length Colonized and RAI: Root Area Index at first (09.07.2007) and second (20.09.2007) harvest 
Am. J. Agri. \& Biol. Sci., 4 (4): 266-277, 2009

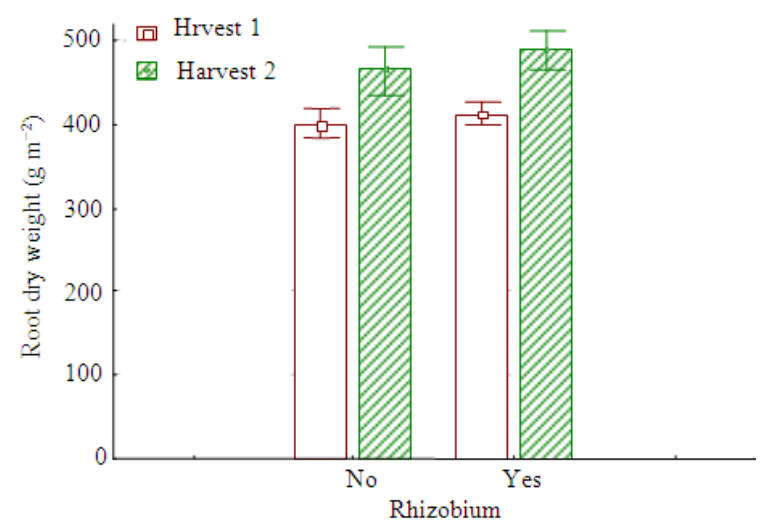

(a)

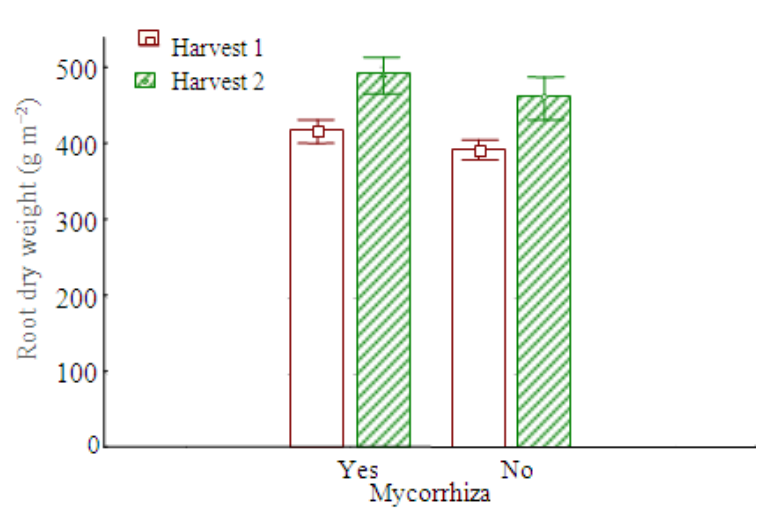

(b)

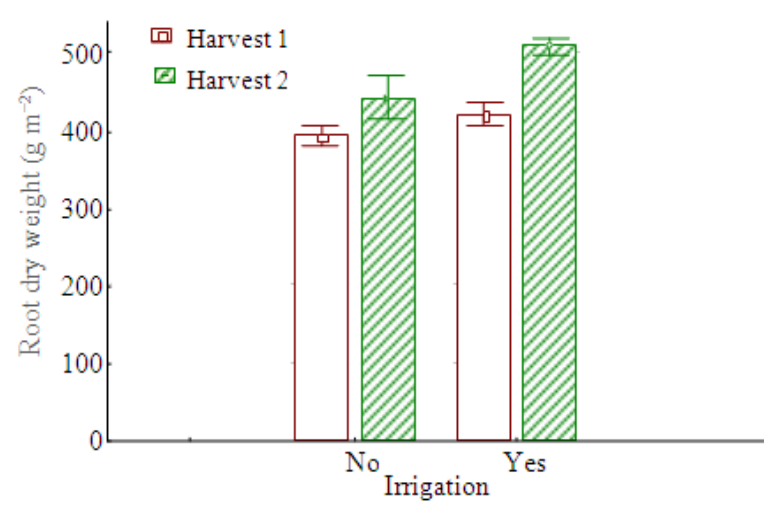

(c)

Fig. 1: Mean comparisons of main effect of rhizobium (a), mycorrhiza (b) and irrigation (c) on root dry weight at first (09.07.2007) and second (20.09.2007) harvest by Duncan's multiple range test ( $\mathrm{p}<0.05)$.

In this experiment, AM colonization varied from $33 \%$ in the non-inoculated treatment at harvest $1-66 \%$ in the AM treated plots at second harvest (Fig. 3a-c). AM inoculation significantly increased AM colonization at $\mathrm{p}=0.05$ and 0.01 at the first and second harvest, respectively (Table 2). At harvest 1 , the effect of AM inoculation on mycorrhizal colonization was more pronounced on irrigation than on non-irrigated plots (Fig. 3c). This can be very favorable for higher water and nutrient uptake under stress conditions. At both harvests, the effects of AM on the non-irrigated plots were similar to the non-inoculated and irrigated plots. This indicates that $\mathrm{AM}$ and irrigation similarly affected AM colonization. The rhizobium $\times$ irrigation interaction was significant at $p=0.01$ only at the second harvest (Table 2). Rhizobium inoculation increased AM colonization on non-irrigated plots and had the opposite effect on irrigated plots (Fig. 3c). The triple interaction of rhizobium $\times$ mycorrhiza $\times$ irrigation also was significant (Table 2). The AM colonization in treatment $\mathrm{R}_{1} \mathrm{M}_{1} \mathrm{I}_{1}$ was higher than in all other treatments at both harvests. Data show that, at both harvests, the effect of AM with irrigation $\left(\mathrm{R}_{0} \mathrm{M}_{1} \mathrm{I}_{1}\right)$ was stronger than the effect of rhizobium with irrigation $\left(\mathrm{R}_{1} \mathrm{M}_{0} \mathrm{I}_{1}\right)$ (Fig. 4d). Generally, inoculation with mycorrhiza had a significant effect in all of evaluated parameters (except root length and specific root length) and according to their mean in second harvest its effect was higher than first harvest. There were only few significant differences between treatments. There is also evidence for alterations of root morphology in response to AM colonization, such as promotion of root elongation.

Frequently, increased formation of laterals and of fine roots has been observed which may be triggered by increased indole-3-butric acid levels of infected roots. Also, increased cytokinin accumulation has been related to lateral roots formation in response to $\mathrm{AM}$ infection ${ }^{[11]}$. Increase the number of putative AM infection sites and thereby promote AM colonization. 


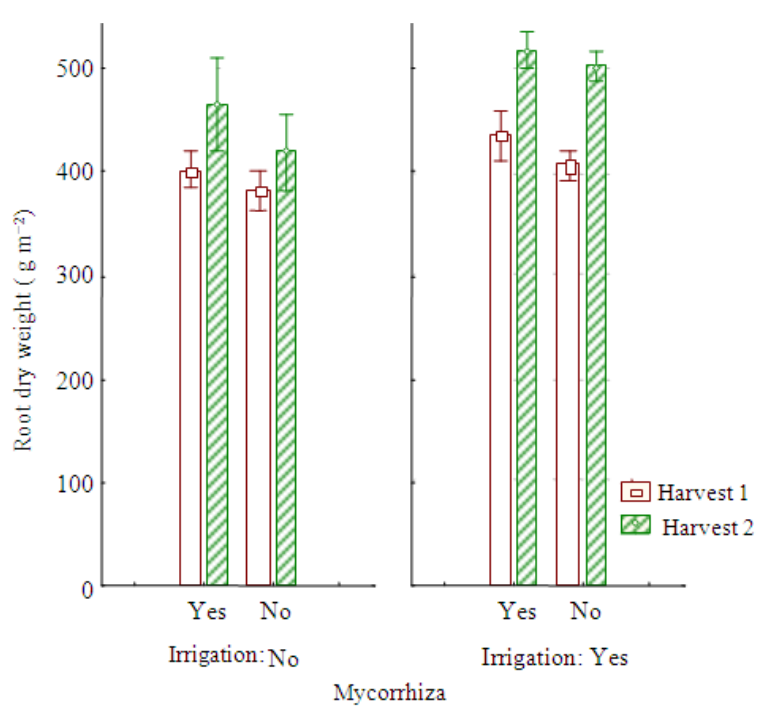

(a)

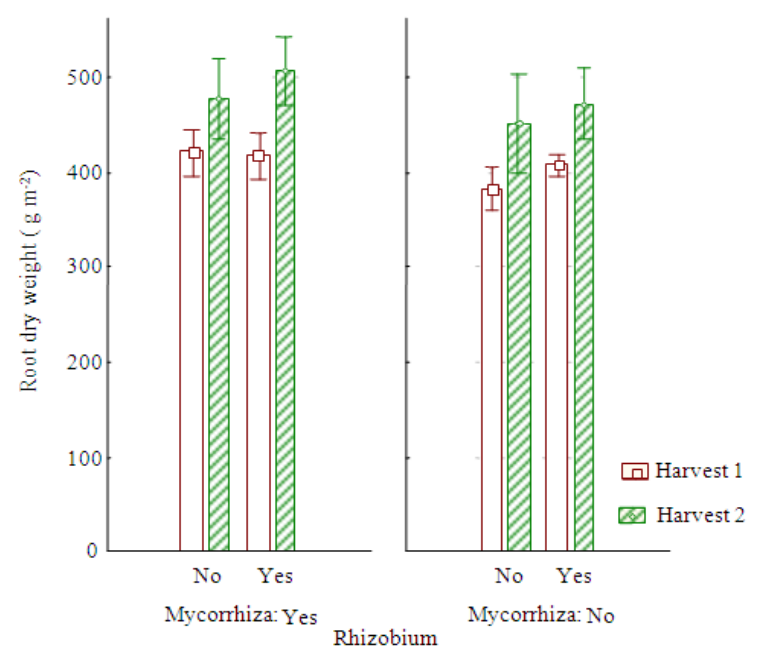

(c)

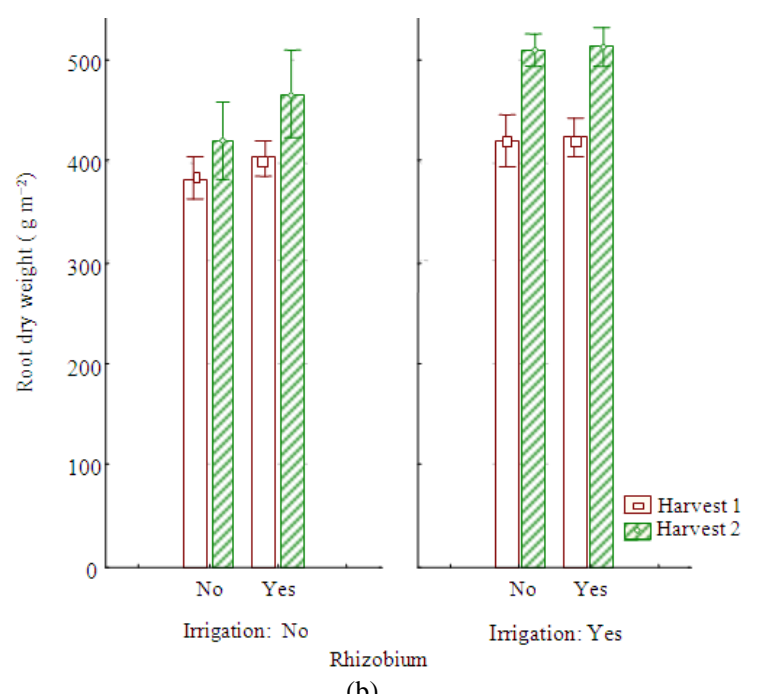

(b)

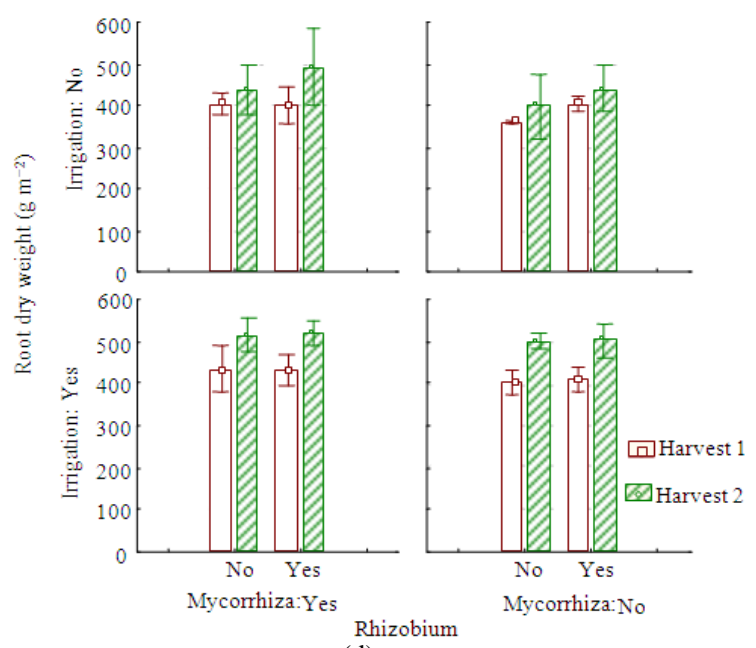

(d)

Fig. 2: Mean comparisons of double interaction effect of mycorrhiza $\times$ irrigation (a), rhizobium $\times$ irrigation (b), rhizobium $\times$ mycorrhiza (c) and triple interaction of rhizobium $\times$ mycorrhiza $\times$ irrigation (d) on root dry weight at first (09.07.2007) and second (20.09.2007) harvest by Duncan's multiple range test ( $\mathrm{p}<0.05)$.

The main effect of rhizobium at the first harvest, the main effect of $\mathrm{AM}$ at the second harvest, the main effect of irrigation at both harvests and the triple interaction of rhizobium $\times \mathrm{AM} \times$ irrigation at the second harvest on mycorrhizal colonization were significant (Table 2). It shows that broadcast of fungal mycelia ameliorate the absorption of nutritional elements by root system and through this process AM create an interaction with internal tissues of root system producing additional water absorption system. Also, a variety of mechanisms may help ameliorate drought stress in mycorrhizal plants thereby enhancing plant recovery after drought. For example, mycorrhizal fungi sometimes increase root length density or alter root system morphology, enabling infected plants to explore more soil volume and extract more water than uninfected plants during drought ${ }^{[19,35]}$. In the second harvest the amount of root weight was $3148-3747 \mathrm{~kg} \mathrm{ha}^{-1}$ and in both harvests R0M0 resulted in the lowest amount. In first harvest all the treatments were in the same group but in the second harvest treatments $\mathrm{R}_{0} \mathrm{M}_{1}$ and $\mathrm{R}_{1} \mathrm{M}_{1}$ resulted in higher relative to the other treatments, producing the amount of 3610 and $3747 \mathrm{~kg} \mathrm{ha}^{-1}$ yield, respectively. 


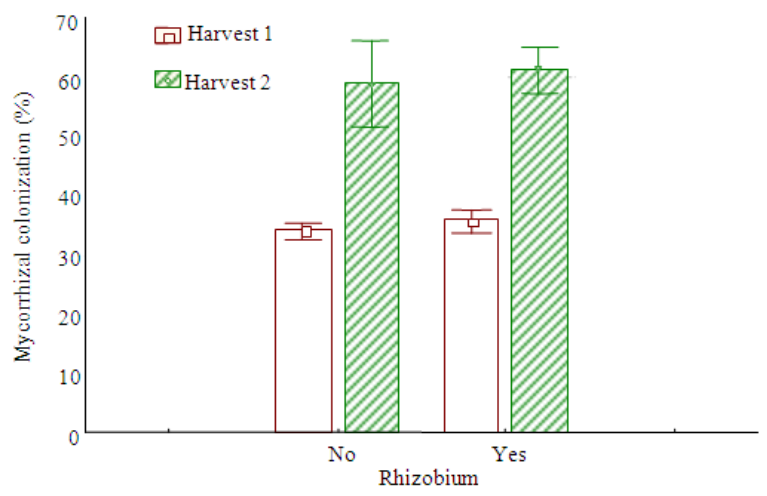

(a)

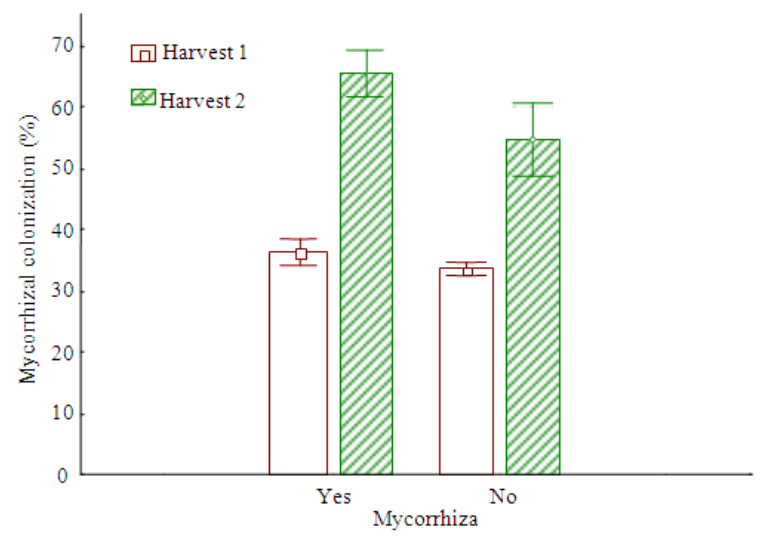

(b)

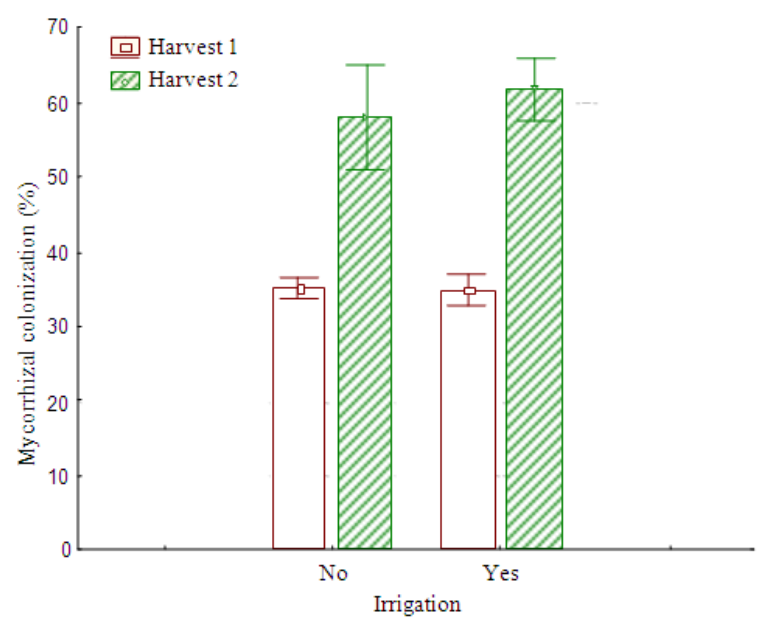

(d)

Fig. 3: Mean comparisons of main effect of rhizobium (a) mycorrhiza (b) and irrigation (c) on mycorrhizal colonization at first (09.07.2007) and second (20.09.2007) harvest by Duncan's multiple range test $(\mathrm{p}<0.05)$

Effect of rhizobium on root length, specific root length and root length colonized in both harvests had significant differences and in the second harvest all of these parameters were higher than first year. Effect of rhizobium on dry weight of mycorrhizal root was significant only in first harvest at 5\% probability level and in second harvest it was higher than first harvest and was not significant. This increasing is regarded to growing the roots between time duration of first harvest until second harvest and also increasing mycorrhizal colonization during this period.

Extensive, deep rooting often has been emphasized in relation to drought resistance ${ }^{[26,37,52]}$. Irrigation in all of the parameters (except mycorrhizal colonization) had significant effect at $1 \%$ probability level. Effect of double interaction of irrigation $\times$ rhizobium on mycorrhizal colonization and dry weight of mycorrhizal root was significant at second harvest and for root length and specific root length in first harvest. These results show that effects of these two parameters together are higher than their individual effect for mentioned parameters. There is not a unique relation between the rate of water uptake from a given soil layer and the root length density in that layer. The relation changes as the soil dries and as the root system grows, ages and senesces. Water affects root growth in many ways. Schnek and Jackson ${ }^{[50]}$ found that the root depth of vegetation was more strongly related to mean annual precipitation. Also, water uptake depends on root size (length or mass), root activity and spatial distribution. Effect of triple interaction of irrigation $\times$ rhizobium $\times$ mycorrhiza on mycorrhizal colonization, dry weight of mycorrhizal root, root length, specific root length and root length colonized was significant only in second harvest. Changing of root architecture and specific root length of plants by AM colonization is described by Auge $^{[4]}$. The best combination of treatments for dry weight of mycorrhizal root were triple interaction of irrigation $\times$ rhizobium $\times$ mycorrhiza and double interaction of irrigation $x$ mycorrhiza with means in second harvest. For root length the best combination of treatments was triple interaction of irrigation $\times$ rhizobium $\times$ mycorrhiza the lowest one belongs to control treatment (witout irrigation, rhizobium and mycorrhiza). Results of mean comparisons by Duncan's multiple range test showed that root area index was higher when rhizobia and mycorrhiza used individually in compare with their dual application. Effect of double interaction of rhizobium $\times$ mycorrhiza on root area index ranged from $13.147\left(\mathrm{R}_{0} \mathrm{M}_{0}\right)$ to $14.697\left(\mathrm{R}_{1} \mathrm{M}_{1}\right)$. Effect of double interaction of rhizobium $\mathrm{x}$ irrigation on this parameter varied from 11.040-14.509 and $\mathrm{R}_{0} \mathrm{I}_{0}$ was at the lowest group. In double interaction of mycorrhiza $x$ irrigation all of treatments were at the same group. 
Am. J. Agri. \& Biol. Sci., 4 (4): 266-277, 2009

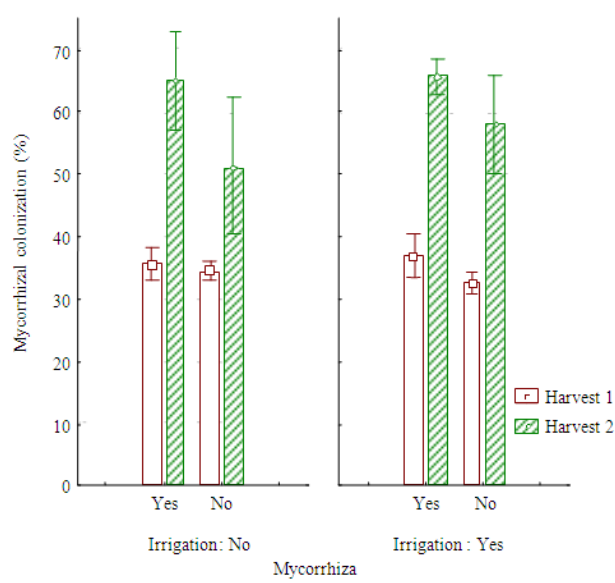

(a)

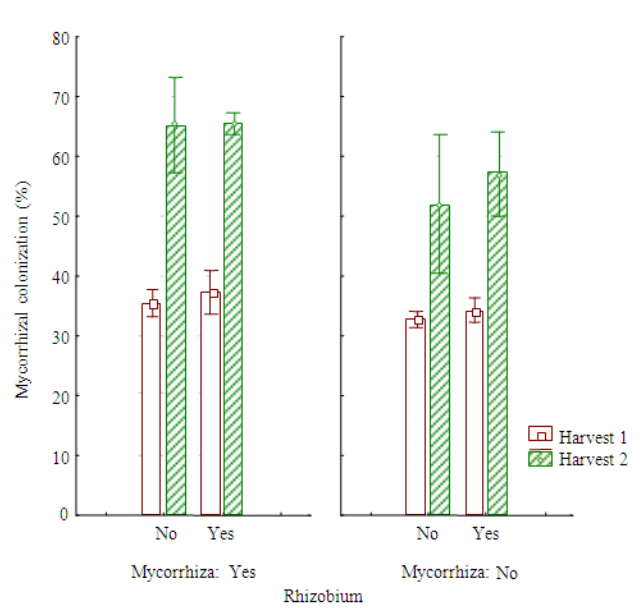

(c)

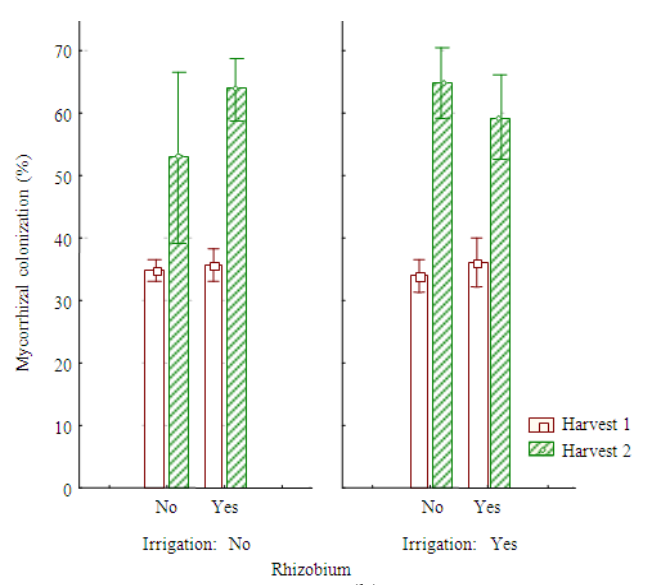

(b)

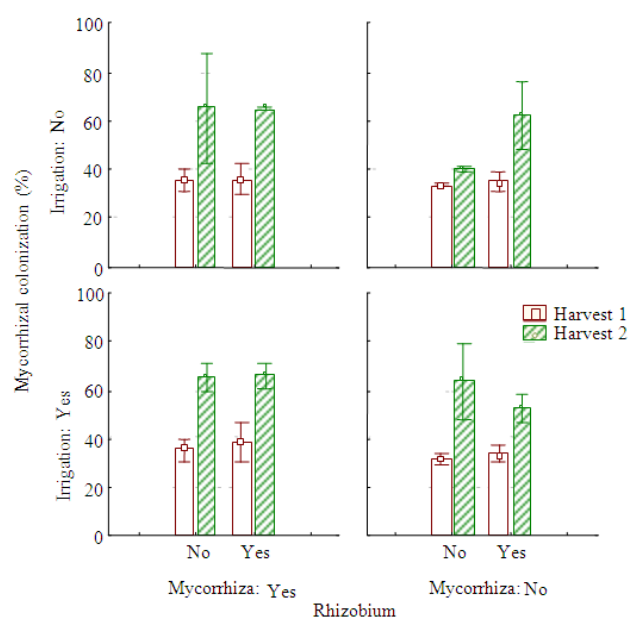

(d)

Fig. 4: Mean comparisons of double interaction effect of mycorrhiza $x$ irrigation (a), rhizobium $x$ irrigation (b), rhizobium $\times$ mycorrhiza $(c)$ and triple interaction of rhizobium $\times$ mycorrhiza $\times$ irrigation $(d)$ on mycorrhizal colonization at first (09.07.2007) and second (20.09.2007) harvest by Duncan's multiple range test $(\mathrm{p}<0.05)$

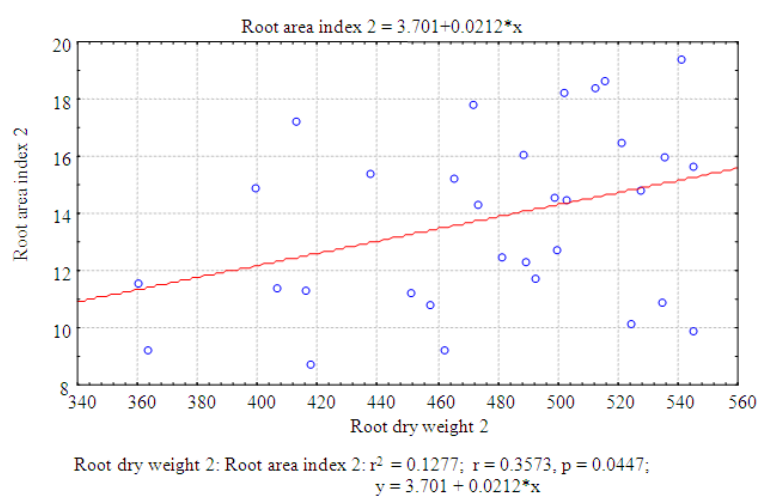

(a)

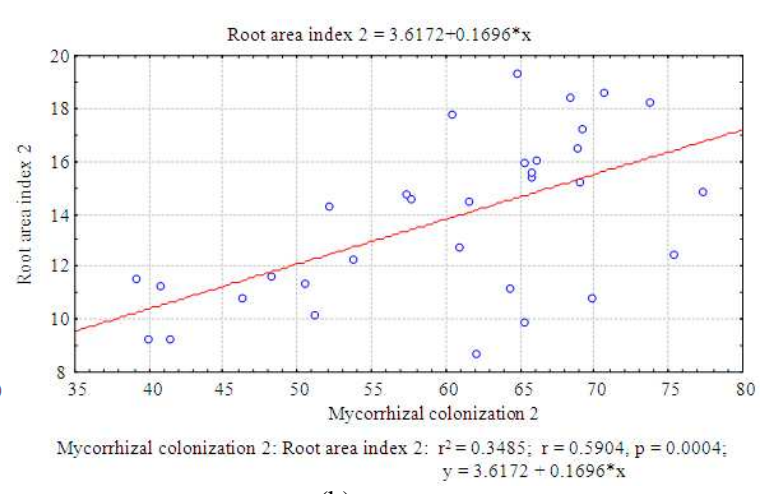

(b)

Fig. 5: Correlation between root area index with root dry weight (a) and mycorrhizal colonization (b) at second (20.09.2007) harvest 
Effect of irrigation was higher than the effect of using mycorrhiza. In triple interaction of rhizobium $\times$ mycorrhiza $\times$ irrigation, root area index was higher than other treatments. Root area index had a positive and significant correlation with Mycorrizal Colonization (MC) and Root Dry Weight (RDW) (Fig. 5a and b).

\section{CONCLUSION}

The amount of remaining roots and its distribution change in conventional and organic fields and also under different extreme condition such as dry condition. In agricultural systems, below ground complementarily between root systems is now considered as a key issue for a successful exploitation of soil resources. In conclusion, Lucerne rhizosphere structure especially in the organic field is highly dynamic and influenced by different factors such as the plant age, water availability and the type of bio-inoculant. There is distance-related effect of the root on the bacterial community of the root-adhering rhizosphere soil was more influence than the one of the rhizoplane/endorhizosphere by modifications in its soil environment, such as an increase in fertilizer input. Also, the results showed that rhizobium and mycorrhiza as two beneficial microorganisms do not have any competition and can improve synergistically the plant resistance to environmental impacts but it was observed that the main effect of each treatment had a powerful and significant effect on most evaluated parameters in compare with their interactions. Because roots are not distributed uniformly with respect to the distance from the plant, the position from which a sample is taken is important if results of different treatments are to be compared. Results showed that increasing water deficit affected root dry weigh, specific root mass and root length significantly at $1 \%$ level and co-inoculation of rhizobium and mycorrhiza with irrigation could increase all root parameters. Data's of variance analysis for mycorrhizal colonization showed that main effect of using mycorrhiza had significant effects on root parameters at 5 and $1 \%$ probability level in first and second harvest, respectively. Results of mean comparisons by Duncan's multiple range test showed that mycorrhizal colonization was higher in R1, M1 and I1 treatments than R0, M1 and I1 treatments in both harvests. Double interaction of M1I1 was at the highest group in both harvests (37.05 and 65.73\%, respectively). Root area index had a positive and significant correlation with Mycorrizal Colonization (MC) and root dry weight (RDW). Therefore, it is crucial to consider compatibility between rhizobium and mycorrhiza community not only for enhanced productivity, but also for the enhanced survival and establishment of legumes growing in less than ideal environmental conditions.

\section{REFERENCES}

1. Allen, M.F., 1982. Influence of vesiculararbuscular mycorrhizae on water movement through Bouteloua gracilis (HBK) Lag Ex Steud. New Phytol., 91: 191-196. DOI: 10.1111/j.14698137.1982.tb03305.x

2. Al-Karaki, G.N. and A. AL-Raddad, 1997. Effect of arbuscular mycorrhizal fungi and drought stress on growth and nutrient uptake of two wheat genotypes differing in drought resistance. Mycorrhiza, $\quad 7$ : 83-88. DOI: 10.1007/s005720050166

3. Arsenault, J., S. Pouleur, C. Messier and R. Guay, 1995. WinRHIZO, a root measuring system with a unique overlap correction method. HortScience, 30: 906-906.

http://www.regent.qc.ca/products/rhizo/RhizoFeatu res.html

4. Auge, R.M., 2001. Water relations, drought and vesicular-arbuscular mycorrhizal symbiosis. Mycorrhiza, 11: 3-42. http://mycorrhiza.ag.utk.edu/reviews/2001_mycorr hiza_review.pdf

5. Azcon, R. and F. El-Atrach, 1997. Influence of arbuscular mycorrhizae and phosphorus fertilization on growth, nodulation and $\mathrm{N}_{2}$ fixation $\left({ }^{15} \mathrm{~N}\right)$ in Medicago sativa at four salinity levels. Biol. Fertility Soil., 24: 81-86. http://cat.inist.fr/?aModele $=$ afficheN\&cpsidt $=2543657$

6. Azcon, R., R. Rubio and J.M. Barea, 1991. Selective interactions between different species of mycorrhizal fungi and rhizobium meliloti strains and their effects on growth, $\mathrm{N}_{2}$ fixation $\left({ }^{15} \mathrm{~N}\right)$ and nutrition of Medicago sativa. New Phytol., 117: 399-404.

http://cat.inist.fr/?aModele $=$ afficheN\&cpsidt $=11388240$

7. Barea, J.M., C. Azcon-Aguilar and R. Azcon, 1987. Vesicular arbuscular mycorrhiza improve both symbiotic $\mathrm{N}_{2}$ - fixation and $\mathrm{N}$-uptake from soil as assessed with a ${ }^{15} \mathrm{~N}$ technique under field conditions. New Phytol., 106: 717-725. DOI: 10.1111/j.1469-8137.1987.tb00172.x

8. Barea, J.M., C. Azcon-Aguilar and R. Azcon, 1988. The role of Mycorrhiza in Improving the Establishment and Function of the RhizobiumLegume System Under Field Condition. In: Nitrogen Fixation by Legumes in Mediterranean Agriculture (Developments in Plant and Soil Sciences), Beck, D. and L.A. Materon (Eds.). Springer, Hague, ISBN: 10: 9024736242, pp: 153-162. 
9. Berkelaar, E. and B. Hale, 2000. The relationship between root morphology and cadmium accumulation in seedlings of two durum wheat cultivars. Can. J. Bot., 78: 381-387. DOI: 10.1139/cjb-78-3-381

10. Bethlenfalvy, G.J., S.M. Brown and W.E. Newton, 1987. Photosynthetic Water and Nutrient Use Efficiency in a Mycorrhizal Legume. In: Mycorrhizae in the Next Decade, Sylvia, D.M., L.L. Hung and J.H. Graham, (Eds.). Institute of Food and Agriculture Sciences of Florisda, Gainsville, FL., pp: 231-223.

11. Bildusas, I.J., R.K. Dixon, F.L. Pfleger and E.L. Stewart, 1986. Growth, nutrition and gas exchange of Bromus inermis inoculated with Glomus fasciculatum. New Phytol., 102: 303-311. DOI: 10.1111/j.14698137.1986.tb00585.x

12. Bohm, W., 1979. Methods of Studying Root Systems. Spriger-Verlag, Berlin, ISBN: 354009329X, pp: 188.

13. Bouma, T.J., K.L. Nielsen and B. Koustaal, 2000. Sample separation and scanning protocol for computerized analysis of root length and diameter. Plant Soil, 218: 185-196. http://cat.inist.fr/?aModele $=$ afficheN\&cpsidt $=1295$ 324

14. Bruulsema, T.W. and B.R. Christie, 1987. Nitrogen contribution to succeeding corn from alfalfa and red clover. Agron. J., 79: 96-100. http://agron.scijournals.org/cgi/content/abstract/79/ $1 / 96$

15. Burke, M.K. and D.J. Raynal, 1994. Fine root growth phonology, production and turnover in a Northern hardwood forest ecosystem. Plant Soil, 162: $135-146$.

http://www.treesearch.fs.fed.us/pubs/2211

16. Campbell, C.A., R.P. Zentner, H.H. Janzen and K.E. Bowren, 1990. Crop Rotation Studies on the Canadian Prairies. Research Branch, Agriculture Canada, ISBN: 0660134225, pp: 133.

17. Cote, B., W.H. Hendershot, J.W. Fyles, A.G. Roy, R. Bradley, P.M. Biron and F. Courshesne, 1998. The phenology of fine root growth in a maple dominated ecosystem: Relationships with some soil properties. Plant Soil, 201: 59-69. http://cat.inist.fr/?aModele $=$ afficheN\&cpsidt $=2338$ 007

18. Daei, G., M.R. Ardakani, F. Rejali, S. Teimuri and M. Miransari, 2009. Alleviation of salinity stress on wheat yield, yield components and nutrient uptake using arbuscular mycorrhizal fungi under field conditions. J. Plant Physiol., 166: 617-625. DOI: 10.1016/j.jplph.2008.09.013
19. Davies, F.T., J.R. Potter and R.G. Linderman, 1992. Mycorrhiza and repeated drought exposure affect drought resistance and extraradical hypahe development of pepper plants independent of plant size and nutrient content. J. Plant Physiol., 139: 289-294.

http://cat.inist.fr/?aModele $=$ afficheN\&cpsidt $=5130$ 603

20. Fahey, T.J. and J.W. Hughes, 1994. Fine root dynamics in a northern hardwood forest ecosystem, Hunnard Brook Experimental Forest, NHJ Ecol., 82: 533-548. http://www.jstor.org/pss/2261262

21. Freyer, B., J.K. Friedel, C. Vogl, G. Pietsch and O. Ehrmann, 2000. Monitoring von Bodenkennwerten in der Umstellung auf Ökologischen Landbau im Trockengebiet Ostösterreichs. https://forschung.boku.ac.at/fis/suchen.projekt_ueb ersicht?sprache_in=de\&menue_id_in=300\&id_in= 3414

22. Garbaye, J., 1994. Helper bacteria: A new dimension to the mycorrhizal symbiosis. New Phytol., 128: 197-210. http://cat.inist.fr/?aModele $=$ afficheN\&cpsidt=3339 699

23. George, E., K.U. Haussler, D. Vetterlein, E. Gorgus and H. Marschner, 1992. Water and nutrient translocation by hyphae of Glomus mosseae. Can. J. Bot., 70: 2130-2137. DOI: 10.1139/b92-265

24. Gill, R. and R. Jackson, 2000. Global patterns of root turnover for terrestrial ecosystems. New Phytol., 147: 13-31. http://www.biology.duke.edu/jackson/np00.html

25. Hardie, K. and L. Leyton, 1981. The influence of vesicular- arbuscular mycorrhizae on growth and water relations of red clover. I. In phospahte deficient soil. New Phytol., 89: 599-608. http://www.jstor.org/pss/2431986

26. Hays, K.L., J.F. Baeber, M.P. Kenna and T.G. McCollum, 1991. Drought avoidance mechanisms of selected bermudagrass genotypes. HortScience, 26: 180-182. http://cat.inist.fr/?aModele $=$ afficheN\&cpsidt $=5458842$

27. Henderson, J.C. and F.T. Davies, 1990. Drought acclimation and the morphology of mycorrhizal Rosa hybrida L. cv. "Frey" is independent of leaf elemental content. New Phytol., 115: 503-510. DOI: 10.1111/j.1469-8137.1990.tb00477.x

28. Himmelbauer, M.L., W. Loiskandl and F. Kastanek, 2004. Estimating length, average diameter and surface area of roots using two different image analyses systems. Plant Soil, 260: 111-120. http://cat.inist.fr/?aModele $=$ afficheN\&cpsidt $=1572$ 4399 
29. Huxley, P., 1996. Biological Factors Affecting form and Function in Woody-Non-Woody Plant Mixtures. In: Tree-Crop Interactions-A Physiological Approach, Ong, C.K. and P.A. Huxley (Eds.). CABI., Wallingford, UK., ISBN: 10: 085198987X, pp: 235-299.

30. Ianson, D.C. and R.G. Lindermann, 1993. Variation in the response of nodulating pigeonpia (Cajanus cajan) to different isolates of mycorrhizal fungi. Symbiosis, 15: 105-109. http://cat.inist.fr/?aModele $=$ afficheN\&cpsidt $=4795$ 018

31. Jackson, R.B., J. Canadell, J.R. Ehlinger, H.A. Mooney, O.E. Sala and E.D. Schulze, 1996. A global analysis of root distributions for terrestrial biomes. Oecologia, 108: 389-411. http://cat.inist.fr/?aModele=afficheN\&cpsidt=2487697

32. Joslin, J.D., M.H. Wolfe and P.J. Hanson, 2001. Factors controlling the timing of root elongation intensity in a mature upland oak stand. Plant Soil, 228: 201-212. DOI: 10.1023/A:1004866705021

33. Keyes, M.R. and C.C. Grier, 1981. Above and below ground root production in 40 year old Douglas fir stands in low and high productivity sites. Can. J. For. Res., 11: 599-605. DOI: $10.1139 / x 81-082$

34. Kirckmann, H. and G. Thorvaldsson, 2000. Challenging targets for future agriculture. Eur. J. Agron., 12: 145-161. DOI: 10.1016/S11610301(99)00053-2

35. Kothari, S.K., H. Marschner and E. George, 1990. Effect of VA mycorrhizal fungi and rhizosphere microorganisms on root and shoot morphology, growth and water relations of maize. New Phytol., 116: 303-311. DOI: 10.1111/j.14698137.1990.tb04718.x

36. Mackie-Dawson, L. and D. Atkinson, 1991. Methodology for the Study of Roots in Field Experiments and Interpretation of Results. In: Plant Root Growth an Ecological Perspective (Special Publication of the British Ecological Society, No 10), Atkinson, D. (Ed.). Blackwell Science inc., Oxford, ISBN: 10: 0632027576, pp: 25-48.

37. Marcum, K.B., M.C. Engelke, S.J. Morton and R.H. White, 1995. Rooting characteristics and associated drought resistance of zoysiagrass. Agron. $\quad$ J., 87 : 534-538. http://agron.scijournals.org/cgi/content/abstract/87/3/534

38. Meek, B.D., D. Rolph, E.R. Rechel, L.M. Carter and W.R. DeTar, 1990. Infiltration rate as affected by an alfalfa and no-till cotton cropping system. Soil Sci. Soc. Am. J., 54: 505-508. http://soil.scijournals.org/cgi/content/abstract/54/2/505
39. Michelsen, A. and S. Rosendahl, 1990. The effect of VA mycorrhizal fungi, phosphorus and drought stress on the growth of Acacia nilotica and Leucaena leucocephala seedling. Plant Soil, 124: 7-13. DOI: 10.1007/BF00010925

40. Miransari, M., H.A. Bahrami, F. Rejali, M.J. Malakuti and H. Torabi, 2007. Using arbuscular mycorrhiza to reduce the stressful effects of soil compaction on corn (Zea mays L.) growth. Soil Biol. Biochem., 39: 2014-2026. http://cat.inist.fr/?aModele $=$ afficheN\&cpsidt $=18802848$

41. Miransari, M., H.A. Bahrami, F. Rejali, M.J. Malakuti and H. Torabi, 2008. Using arbuscular mycorrhiza to reduce the stressful effects of soil compaction on wheat (Triticum aestivum L.) growth. Soil Biol. Biochem., 40: 1197-1206. DOI: 10.1016/j.soilbio.2007.12.014

42. Pacovsky, R.S., 1988. Influence of inoculation with Azospirillum brasilense and Glomus fasciculatum on sorghum nutrition. Plant Soil, 110: 283-287. DOI: $10.1007 / \mathrm{BF} 02226809$

43. Pietsch, G., 2004. $\mathrm{N}_{2}$-Fixierungsleistung und wasserverbrauch von futterleguminosen im okologischen landbau unter den klimatischen bedingungen der pannonischen region osterreichs. Dissertation Universitat fur Bodenkulture, Wien. http://orgprints.org/3080/

44. Pietsch, G., J.K. Friedel and B. Freyer, 2007. Lucerne management in an organic farming system under dry site conditions. Field Crops Res., 102: 104-1118. DOI: 10.1016/j.fcr.2007.03.003

45. Polomski, J. and N. Kuhn, 2000. Kahlschlagbedingte veranderungen im wurzelraum eines buchenniederwaldes auf rendzina. 10: Borkheider seminar zur oekophysiologie des wurzelraumes. Stuttgart, Germany; BG Teubner, pp: 65-71. http://edoc.huberlin.de/habilitationen/beinert-thomas-2001-0410/PDF/Beinert.pdf

46. Reganold, J.P., A.S. Palmer, J.C. Lockhart and A.N. Macgregor, 1993. Soil quality and financial performance of biodynamic and conventional farms in New Zealand. Science, 260: 344-349. DOI: $10.1126 /$ science.260.5106.344

47. Roseti, D., R. Gaur, B.N. Johri, G. Imfeld, S. Sharma, K. Kawaljeet and M. Arango, 2006. Plant growth stage, fertilizer management and bio-inoculation of arbuscular mycorrhizal fungi and plant growth promoting rhizobacteria affect the rhizobacterial community structure in rain-fed wheat fields. Soil Biol. Biochem., 38: 1111-1120. http://cat.inist.fr/?aModele $=$ afficheN\&cpsidt $=1773$ 2313 
48. Santantonio, D. and J.C. Grace, 1987. Erratum: Estimating fine root production and turnover from biomass and decomposition data: A compartmentflow model. Can. J. For. Res., 17: 900-908. http://article.pubs.nrccnrc.gc.ca/RPAS/rpv?hm=HInit\&afpf=x88100.pdf $\&$ journal $=$ cjfr $\&$ volume $=18$

49. SAS Institute, 1990. SAS/STAT User's Guide, Version 6. 4th Edn., SAS Institute, Cary North Carolina, ISBN: 10: 1555443761, pp: 1848.

50. Schenk, H.J. and R.B. Jackson, 2002. Rooting depth, lateral root spreads and belowground/above-ground allometries of plants in water-limited ecosystems. J. Ecol., 90: 480-494. http://www.biology.duke.edu/jackson/jecol02.htm

51. Rao, N.S.S., K.V.B.R. Tilak and C.S. Singh, 1985. Effect of combined inoculation of Azospirillum brasilense and vesicular arbuscular mycorrhiza on pearl millet (Pennisetum americanum). Plant Soil., 84: 283-286. DOI: 10.1007/BF02143192

52. Taylor, H.M., 1983. A Program to Increase Plant Available Water through Rooting Modification. In: Root Ecology and its Practical Application: A contribution to the Investigation of the Whole Plant, Bohm, W. (Ed.). Bundesanstalt fur Alpenlandische Landwirtschaft, Austria, pp: 463-472.
53. Tennant, D., 1975. A test of a modified line intersect method for estimating root length. J. Ecol., 63: 995-1001. http://www.jstor.org/stable/2258617

54. Vierheilig, H., A.P. Coughlan, U. Wyss and Y. Piche, 1998. Ink and vinegar, a simple staining technique for arbuscular-mycorrhizal fungi. Applied Environ. Microbiol., 64: 5004-5007. http://www.pubmedcentral.nih.gov/articlerender.fc gi? $\operatorname{artid}=90956$

55. Deckers, J.A. F.O. Nachtergaele and O.C. Spaargaren, 1998. World Reference Base for Soil Resources. ACCO, Rome, ISBN: 9033441241, pp: 165.

56. Xavier, L.J.C. and J.J. Germida, 2002. Response of lentil under controlled conditions to co-inoculation with arbuscular mycorrhizal fungi and rhizobia varying in efficacy. Soil Biol. Biochem., 34: 181-188. DOI: 10.1016/S0038-0717(01)00165-1 